\title{
旭川の大原箇所における植生の生長と 洪水時の植生流出条件の検討 \\ INVESTIGATION OF VEGETATION GROWTH AND WASH-OUT CONDITION DURING FLOOD EVENT AT OHARA AREA IN THE ASAHI RIVER
}

\author{
前野詩朗 $^{1} \cdot$ 吉田圭介 $^{2} \cdot$ 三島望 ${ }^{3} \cdot$ 松山悟 $^{4}$ \\ Shiro MAENO, Keisuke YOSHIDA, Nozomi MISHIMA and Satoru MATSUYAMA \\ 1 フェロー会員 博士(工) 岡山大学大学院教授 環境生命科学研究科（干700-8530 岡山市北区津島中 3-1-1） \\ 2 正会員 博士(工) 岡山大学大学院准教授 環境生命科学研究科（同上） \\ 3 学生会員 岡山大学大学院環境学研究科社会基盤環境学専攻（同上） \\ 4 非会員 岡山大学環境理工学部環境デザイン工学科（同上)
}

\begin{abstract}
The forestation in rivers causes several problems, because it reduces river flow capacity, and the forestation by invasive spices sometimes affects endemic species and the biodiversity in a river habitat. The wash-out of vegetation during a flood is known to be a reasonable measure for preventing the forestation. However, the relationship among the wash-out condition, a river discharge and a bed deformation has not been clarified yet. This paper investigates the vegetation growth rate and the wash-out condition of vegetation during the flood at Ohara area in the Asahi River, based on the field observations and the numerical simulations. The observation results showed that the large discharge during the flood induced the bed deformation and the wash-out of vegetation, and the simulated results indicated that the non-dimensional bed shear stress of $d_{85}\left(\tau_{* 85}\right)$ can evaluate the washed-out condition more suitably.
\end{abstract}

Key Words : field observations, gravel bar, vegetation management, flood flow simulation

\section{1.はじめに}

岡山市を流れる一級河川旭川では，1980 年代以降， 砂州上で植生が繁茂するようになり，河道内の樹林化 が進行し，礫河原が減少している。これは，旭川ダム (1954 年)，湯原ダム（1955 年）が建設され洪水規模 が縮小したこと，1960 年代以降の河床掘削による土砂 供給量が減少したことなどが原因として考えられる.

樹林化の進行は，礫河原固有の植生の減少，あるい は流下能力の低下といった治水上の問題などを引き起 こすため，植生を除去し，砶河原を再生させることは 大変重要である，旭川では，礫河原を再生させるため に，図-1 に示している大原試験区（2004 年 3 月），祇 園試験区（2005 年 3 月）で砂州の切り下げと植生の伐 採などの現地試験 ${ }^{1), 2)}$ が実施され，その後，モニタリン グ ${ }^{3)}$ も行われている。また，玉柏試験区（2009年 1 月） では植生の伐採が行われている. しかし, 植生の伐採・ 除去などの人による作業はできる限り減らし，小，中 規模の出水により, 自律的に植生が除去され, 碩河原 が再生・維持されることが理想である. そのためには,
どの程度の規模の洪水で植生の流出が起こるのかを把 握する必要がある。

河道内植生の流出に関して，八木澤ら ${ }^{4)}$ は砂碟洲に 繁茂した樹木が流出し裸地するための洪水流量規模を 推定し，流出限界せん断力を明らかにしている. 田中 $ら^{5)}$ は砂州上に繁茂した樹木の出水による流出実績か ら，抗力モーメントより底面せん断力の方が樹木の流 出を評価できることを示し，繁茂場所の違いによる流 出限界值の相違を明らかにしている。 また，平川ら ${ }^{6)}$ は出水前後の砂州の現地調査と河床変動解析から草本 植生の破壊状況を明らかにしている。このように植生 の流出条件等を評価する研究が行われているが，研究 例は少ないため，今後河道管理のための精度良い植生 の消長モデルを確立するためには，さらに多くの知見 が必要である。

そこで，本論文では，2008 年から継続して行ってい る旭川大原箇所の碩河原を対象とした植生と河床変動 の現地調査結果と 2011 年 9 月 3 日に発生した洪水の数 值シミュレーション結果から, 洪水が植生の流出に及 ぼす影響について検討する。 


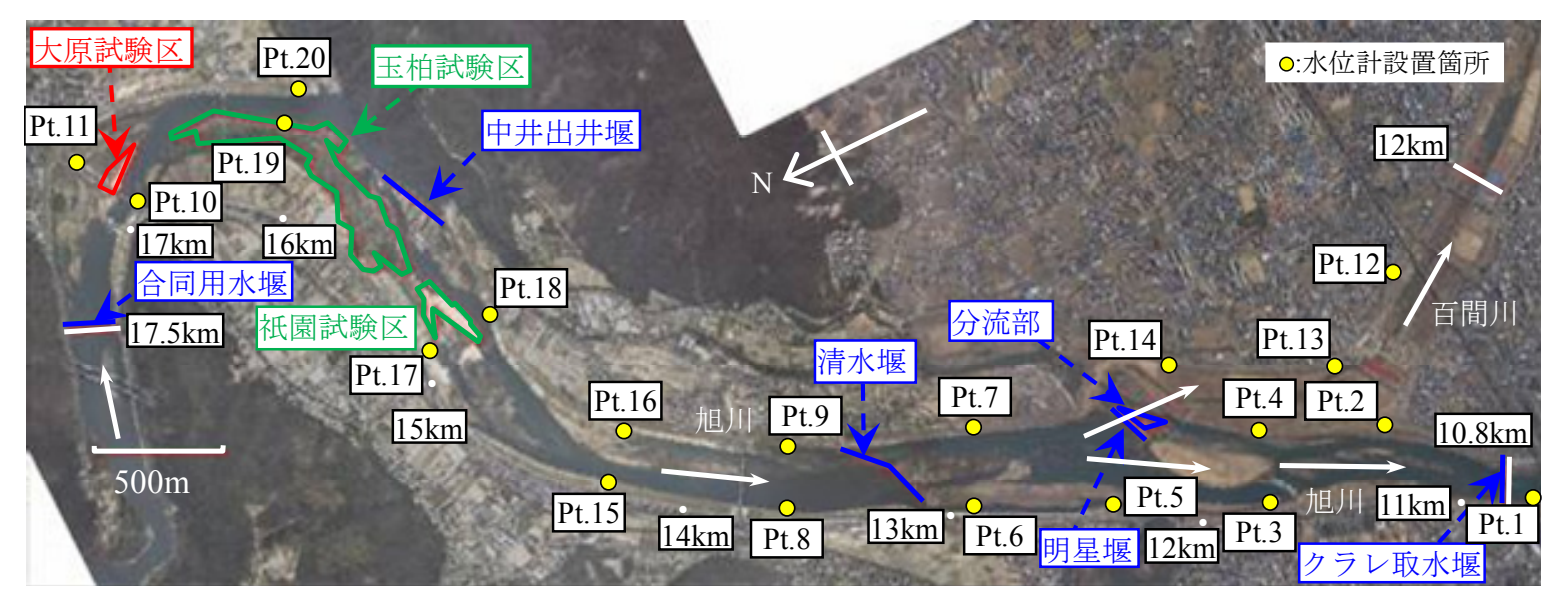

図-1＼cjkstart対象区域と水位計設置箇所

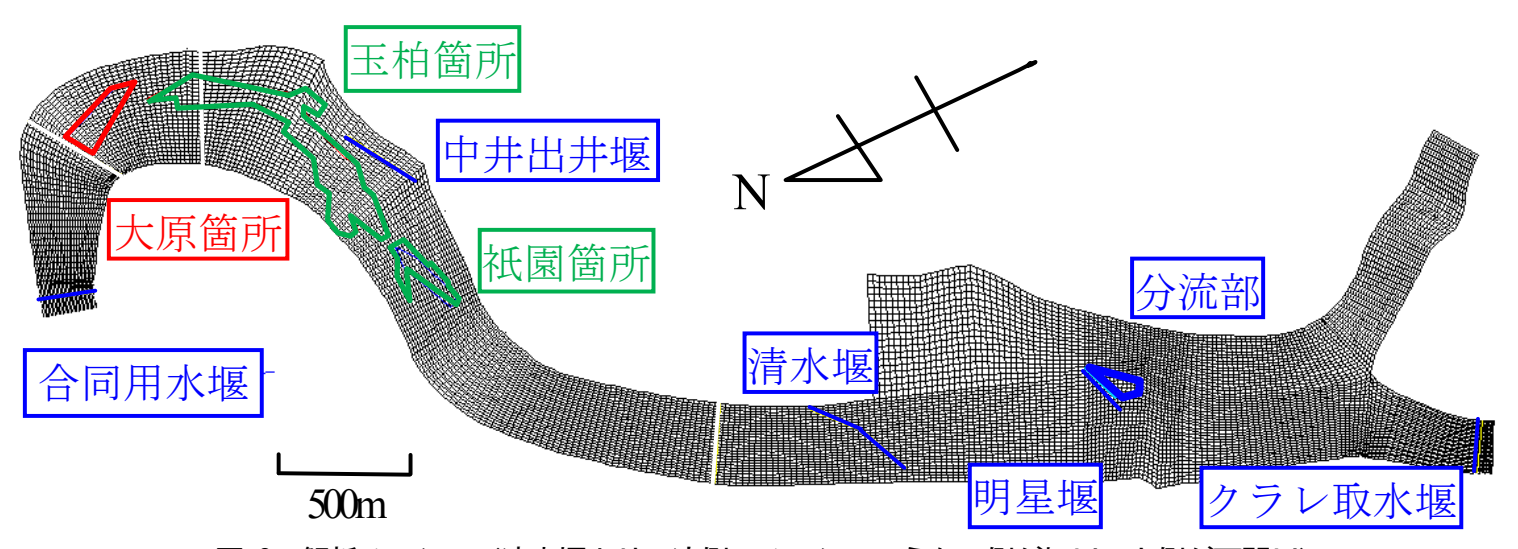

図-2 解析メッシュ（清水堰より下流側のメッシュのうち下側が旭川，上側が百間川）

\section{2. 数値解析}

\section{(1) 解析の概要}

本研究の対象区間は図-1 に示す旭川の河口から $10.8 \mathrm{~km} \sim 17.5 \mathrm{~km}$ 区間之，旭川の放水路である百間川の河 口から $12.0 \mathrm{~km}$ より上流の区間である.この区間の河道幅 は約 $300 \mathrm{~m}$ ，平均河床勾配は $1 / 670$, 河床材料の平均粒径 は $30 \mathrm{~mm}$ 程度である.

図-1 に示す旭川の $10.6 \mathrm{~km} \sim 16.9 \mathrm{~km}$ 区間に Pt.1〜Pt.11, Pt.15〜Pt.20の 17 箇所, 百間川の $12.5 \mathrm{~km} \sim 13.6 \mathrm{~km}$ 区間に PT.12〜Pt.14の3 箇所に絶対圧型水位計 (S\&DL_mini/10m レンジ) を設置した。これらの水位計により得られた実 測水位と解析水位を比較することで植生による流水抵抗 の妥当性を検討する. なお，Pt.19 に設置した水位計につ いては，洪水により流失したため，水位データを計測す ることができなかった.

2011 年 9 月 3 日に発生した洪水の数值シミュレーショ ンを行った. 2011 年 9 月洪水は, 河口から 19.0km の地 点にある下牧観測所で 9 月 3 日 21 時 40 分に最大流量が $3403 \mathrm{~m}^{3} / \mathrm{s}$ に達する洪水となった（流量ハイドログラフを 図-10 に示している). 2011 年 9 月洪水ピーク流量時の大 原箇所（図-1 中の赤枠内に示卞現地調査の対象箇所）の 冠水深は 4〜 $5 \mathrm{~m}$ 程度であった。

\section{（2） 解析モデルと解析条件}

本研究では，前野ら ${ }^{7)}$ が同区間を対象として解析を行 っている平面 2 次元モデルを用いた. このモデルは植生 の柔らかさや，摩擦速度により倒伏の影響を考慮できる モデルであり洪水時の流況の再現性が検証されている.

図-2 は，本研究で用いた解析メッシュを示している．旭 川と百間川のメッシュはそれぞれ別々に作成しており， 結合部分でデータのやり取りを行っている，旭川は，流 下方向に 326 , 横断方向に 29 の節点を, 百間川は流下方 向に 138，横断方向に 20 の節点を設けた. メッシュの格 子間隔は $20 \mathrm{~m}$ 程度である. 河床高は, デジタル航空カメ ラ (平成 18 年度撮影) で測量されたデータを用い, 水面 下の部分については, $200 \mathrm{~m}$ ピッチの定期横断測量データ を用いて内挿した．また，河床高のデータが得られてか ら 2011 年 9 月洪水までの間で, 局所的に河床が変化して いる箇所もあるが，メッシュ平均の河床高に影響を与え るような大きな変化は起きていない. また, 植生密生度, 植生高から形状抵抗力を求めている.

2011 年 9 月洪水の再現を行うため 9 月 3 日 6 時から 9 月 4 日 18 時までの 36 時間を対象に数值解析を行った. 9 月 3 日 6 時の流量と下流端水位を与え, 平面 2 次元不等 流計算を行い初期条件とした. その後, 河床変動を考慮 せずに非定常計算を行った。 


\section{3. 現地調査の方法}

\section{（1）調查箇所の概要}

図-1 に示寸大原試験区において 2008 年 7 月から 2012 年 8 月までの約 4 年間現地調查を行った. 大原箇所は, 旭川河口からの距離が約 $16.8 \mathrm{~km}$ の低水路左岸水際に位 置している. 碩河原再生の試験区として 2004 年 3 月に整 備が行われている (図-3). 砂州の土砂が堆積した部分の 縦断方向に約 $140 \mathrm{~m}$, 横断方向に約 $40 \mathrm{~m}$ の範囲で植生の

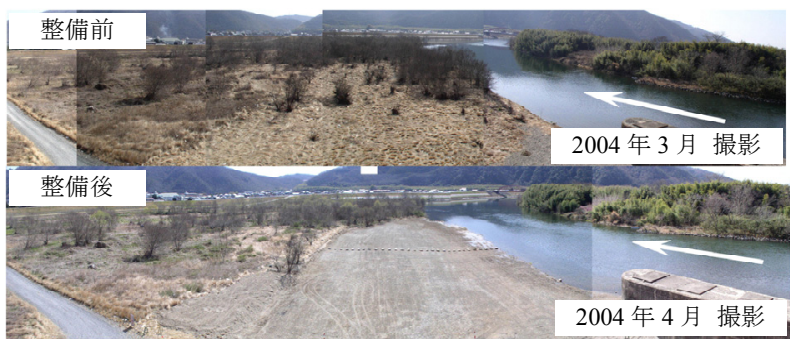

図-3 大原箇所の整備前後の景観 3

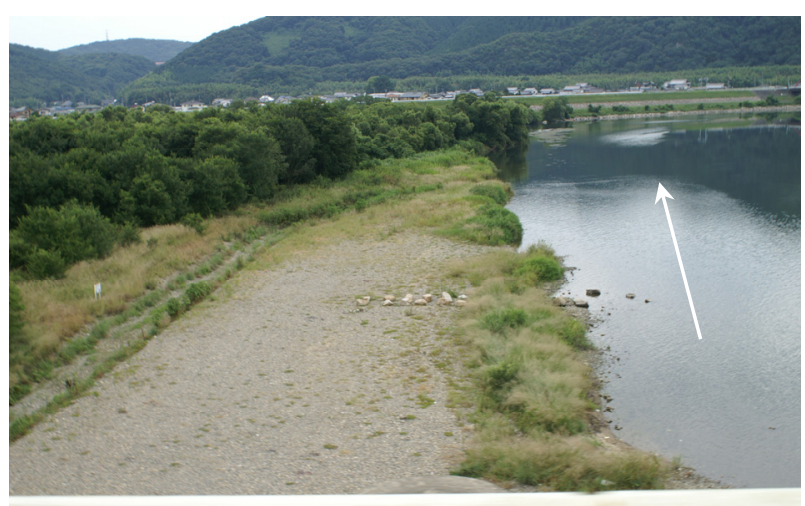

図-4 大原箇所の景観（2008 年 7 月撮影）

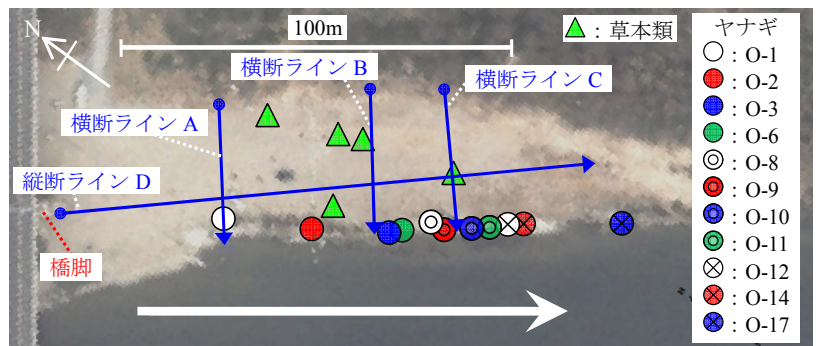

図-5＼cjkstart対象植生の位置および横断・縱断ライン
除去と 1〜2m 程度の砂州の切り下げが行われた. しかし， 図-4 に示寸ように 2008 年には, 水際部と下流側に植生 が再び繁茂していることがわかる.

\section{(2) 植生調査}

\section{a) 木本類}

木本類は大原箇所の水際部に優先的に繁茂しているヤ ナギ類を対象とした（以下，ヤナギと呼ぶ)。. 2008 年の 現地調査開始当初は，17 本（O-1〜O-17）のヤナギを選 定したが, 調查開始後すぐに 6 本が人為的に除去されて しまった. そこで，図-5 に示寸水際部に残った 11 本の ヤナギについて，標尺を用いて樹高を測定した，位置座 標については, RTK-GPS（精度 $\pm 3 \mathrm{~cm}$ 程度）を用いて緯 度, 経度を測定した。 また, 出水による流出や倒伏につ いても観測を行った。

\section{b) 草本類}

草本類は，ヨモギ (2本)，オオブタクサ，シナダレス ズメガヤ，ハシカグサの 4 種類を 5 本選定し，出水によ る流出や埋没について観測した. 図-5 に選定した草本類 の位置を示す。

\section{（3）河床変動調査}

図-5に示寸ように横断ライン 3 本, 縦断ライン 1 本を 選定し, 大規模な出水前後を含め, 年に数回測量し, 出 水による河床変動についての調査を行った.

\section{（4）河床粒径調査}

無次元掃流力を算出するために用いた河床粒径は, 2008 年 7 月に大原箇所の 3 地点で, 縦 $50 \mathrm{~cm}$, 横 $50 \mathrm{~cm}$, 深さ $5 \mathrm{~cm}$ で河床を採取し, ふるいわけ試験により求めた.

\section{4. 現地調査結果と考察}

\section{(1) ヤナギの樹高}

図-6 は調查期間中のヤナギの樹高と $1000 \mathrm{~m}^{3} / \mathrm{s}$ 程度以上 の出水状況について示している. 2008 年 7 月 31 日時点 では，対象としている 11 本のヤナギの平均樹高は，約 $1.65 \mathrm{~m}$ で，最も高いもので $2.45 \mathrm{~m}$ であった. 2011 年 9 月

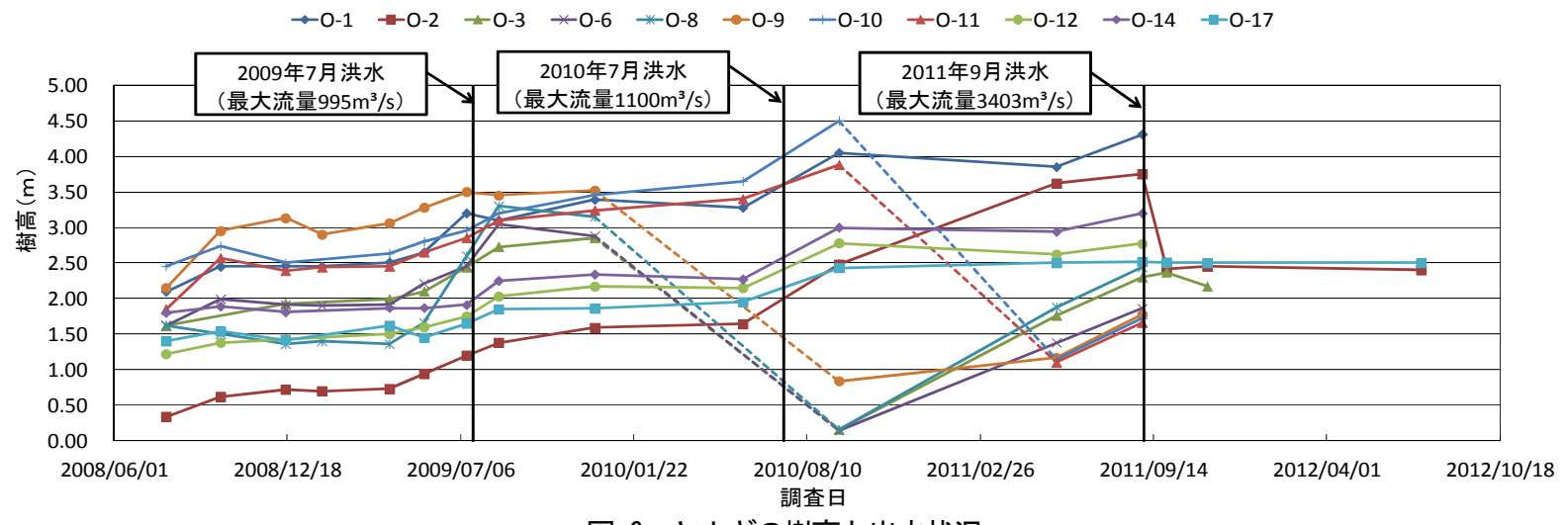

図-6 ヤナギの樹高と出水状況 


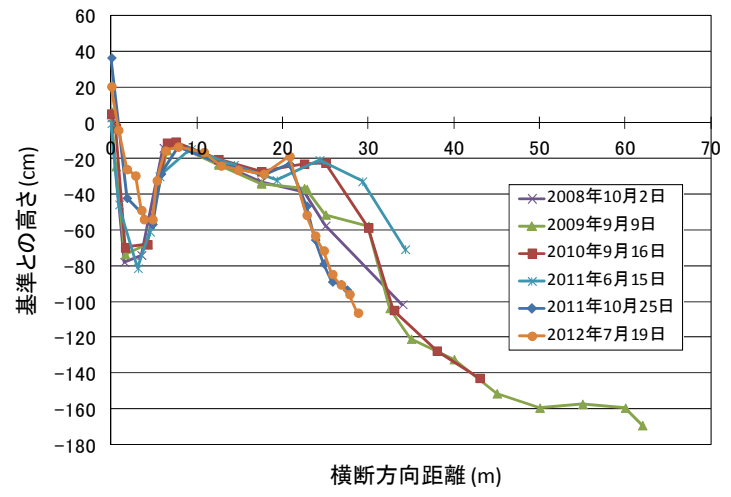

(a) 横断ラインA の河床変動

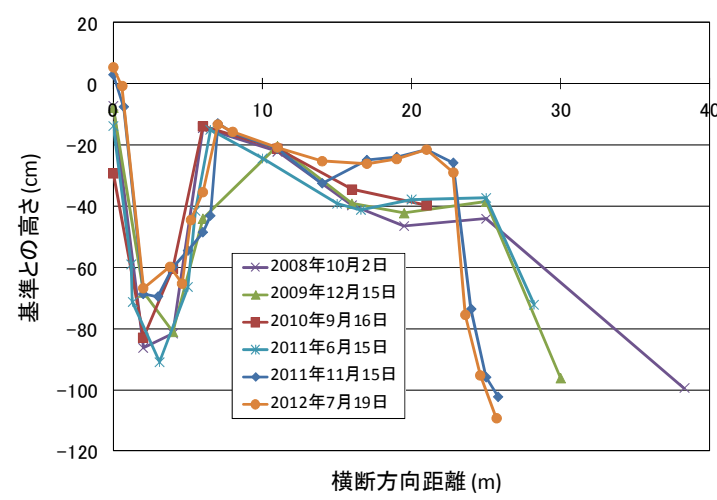

(c) 横断ラインCの河床変動

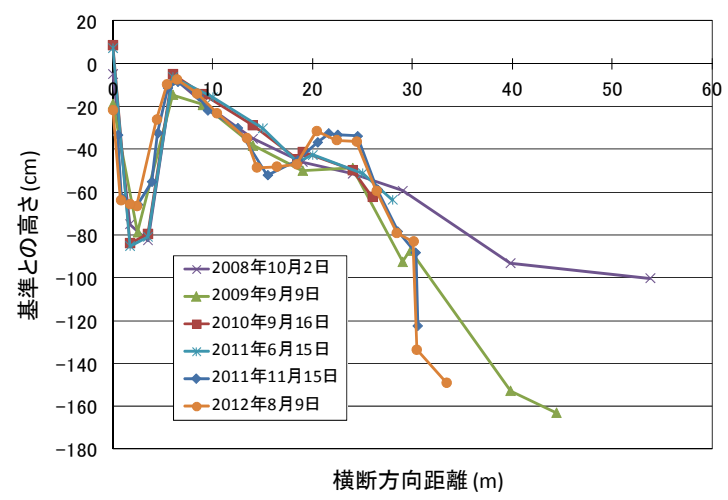

(b) 横断ラインB $B$ の河床変動

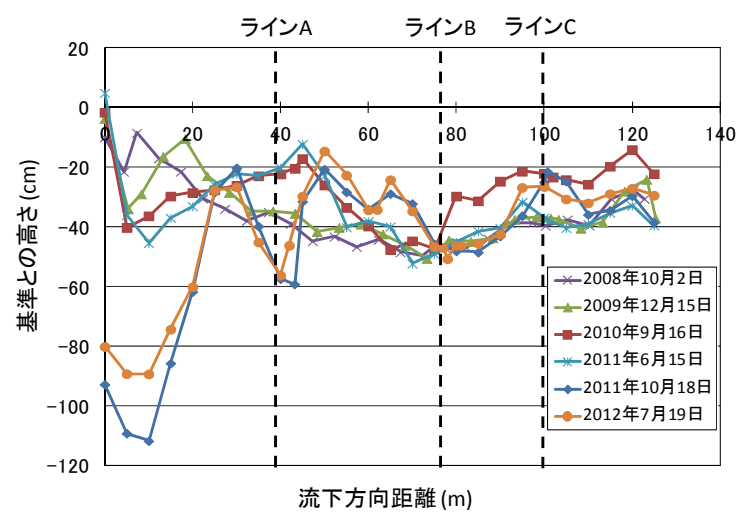

（d） 縦断ラインDの河床変動

図-7 各ライン上の河床変動

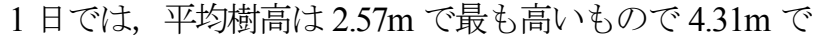
あった. また，図-6の点線箇所のように調査期間中に人 為的に伐採されたヤナギもあった. 伐採による影響を除 くと年間約 $0.85 \mathrm{~m}$ の速度で樹高が生長していることがわ かった. さらに, 夏季の方が速く生長し, 冬季はほとん ど生長しない. 年間の生長速度は, 渡辺ら ${ }^{8)}$ が明らかに した伐採されたヤナギの生長速度と概䄈一致する. また， 池田ら 9)が構築したハリエンジュ（ヤナギと同じ木本類） の生長モデルにおいても, 樹齢 5 年で樹高が $4 \mathrm{~m}$ 程度に 生長することが示されており, 生長速度はほぼ一致して いる.

\section{（2）植生の流出状況}

図-6 に示寸ように流量が $1000 \mathrm{~m}^{3} / \mathrm{s}$ 程度の 2009 年 7 月 洪水と 2010年7月洪水では, ヤナギは流出しなかったが, 2011 年 9 月洪水により対象 11 本のうち 8 本のヤナギが 流出した (図-6 中のデータが失われている箇所が流出し たヤナギ). O-2 は傾斜した状態となり，O-3 は根が露出 して抜けそうな状態となった. 調査対象のヤナギの中で, 最下流に位置する O-17 は, ほぼ直立状態で維持されてい た.これは，上流側に繁茂している植生群が抵抗となり， O-17への洪水の影響が抑えられたと考えられる.

一方, 草本類は $1000 \mathrm{~m}^{3} / \mathrm{s}$ 程度の洪水では流出しなかっ たが, 2011 年 9 月洪水により調査対象の草本類は全て流 出か埋没した.

\section{（3）河床変動}

図-7 は図-5 の各ライン上の河床変動を示している. 橋 脚の定点（TP：10.7m）を基準として, 各横断ラインは 陸側を始点, 縦断ラインは橋脚下流端を始点としている.

図-7 (c) に示寸横断ラインCは, 2011 年 6 月 15 日から 2011 年 11 月 15 日の期間で横断距離 $25 \mathrm{~m}$ 付近の河岸が大 きく侵食されている. これは 2011 年 9 月洪水によるもの で，この侵食でヤナギが生育基盤ごと流出したと考えら れる. 一方, 横断距離 $20 \mathrm{~m}$ 付近で $20 \mathrm{~cm}$ 程度堆積してお り, 今後冠水頻度の低下により, 植生が定着し, 繁茂す る可能性がある. そこで，早めに堆積した箇所の砂州の 切り下げなどを行い，小規模の洪水でも水が流れるよう にし，植生の発達を抑えることが望ましい. このような 河岸側の侵食と堆積は横断ライン A， B でもみられた.

図-7 (d) は図-5 に示寸縦断ライン D 上の河床変動を示 している. 2008 年〜2010 年の間で, $20 \mathrm{~cm}$ 程度の河床変 動をしている箇所がみられる. この期間中は, $1000 \mathrm{~m}^{3} / \mathrm{s}$ 規模の洪水が 2 度発生しており，この洪水の影響により 河床変動が起こったと考えられる. 2011 年 6 月 15 日か ら 2011 年 10 月 18 日の期間で, 橋脚下流側が約 $1 \mathrm{~m}$ 洗掘 し，流下方向に沿って洗掘と堆積を交互に繰り返すよう な河床形状となっている. これは, 2011 年 9 月洪水によ るものと考えられる. また, 上流側と比較すると, 下流 側で洗掘・堆積などの砂礫の移動があまりみられないの は，図-4に示すように下流側で草本類が繁茂し，土砂移 動を妨げているためと考えられる. 


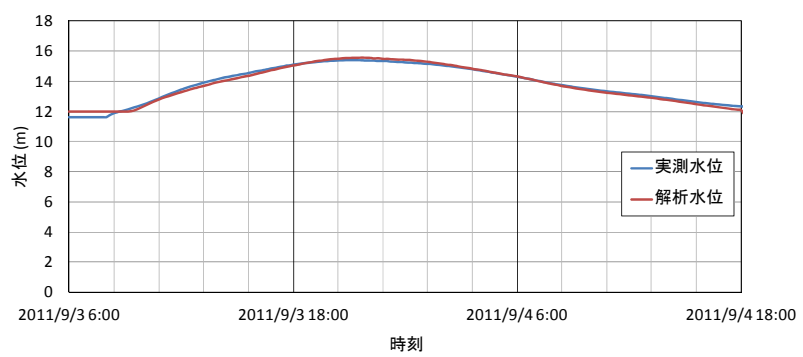

図-8 大原箇所の最寄り水位計設置箇所 (Pt. 11) の実測水位と 解析水位

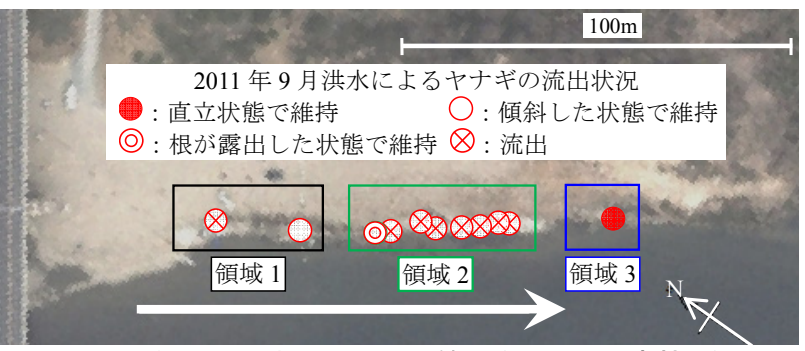

図-9 2011 年 9 月洪水による大原箇所(図-1 中の赤枠内) のヤ ナギの流出状況とヤナギの繁茂場所による領域区分

\section{5. 解析結果および考察}

\section{（1） 2011 年 9 月洪水の実測水位と解析水位の比較}

植生の影響を考慮した数值解析の妥当性を評価するた めに水位計を設置し，実測水位と解析水位を比較した. 図-8 は，旭川の河口から 16.9km の左岸に位置する Pt.11 (TP : 11.62m) に設置した水位計の実測水位と解析水位 を示しており，両者の水位はほぼ一致している。困には 掲載していないが他の計測点の実測水位と解析水位も 概ね一致しており，植生による流水抵抗が正しく評価さ れ, 2011 年 9 月洪水において精度良く再現できていると いえる。

\section{（2）無次元掃流力と植生流出の関係の検討}

河床の通過重量百分率の $50 \% ， 80 \% ， 85 \% ， 90 \%$ 粒径 の砂碩が移動する場合を考えて，大原箇所での河床粒径 $d_{50}=28 \mathrm{~mm}, d_{80}=49 \mathrm{~mm}, d_{85}=54 \mathrm{~mm}, d_{90}=59 \mathrm{~mm}$ で算出 した無次元掃流力と植生の流出の関係を検討寸る. その 際, 河床材料が移動し始める無次元掃流力が 0.05 以上と なることを植生の流出の条件とした.

図-9 は2011 年 9 月洪水による大原箇所（図-1 中の河 口から 16.6〜 16.8km 地点の赤枠内）のヤナギの流出状況 とヤナギが繁茂している場所を領域 1 (上流域)，領域 2 (中流域), 領域 3 (下流域) の 3 つ領域に区分したも のを示している. 図-10 は各領域ごとの無次元掃流力の 時間変化と下牧観測所での HQ 式より算出した流量ハイ ドログラフを示している. 無次元掃流力の值は各領域内 に含まれる計算格子点上の無次元掃流力の值を平均化 した值である．流量がピークに達したときに無次元掃流 力が最も大きくなっていることがわかる.

$50 \%$ 粒径のときは，流量が $1000 \mathrm{~m}^{3} / \mathrm{s}$ 程度になると全て

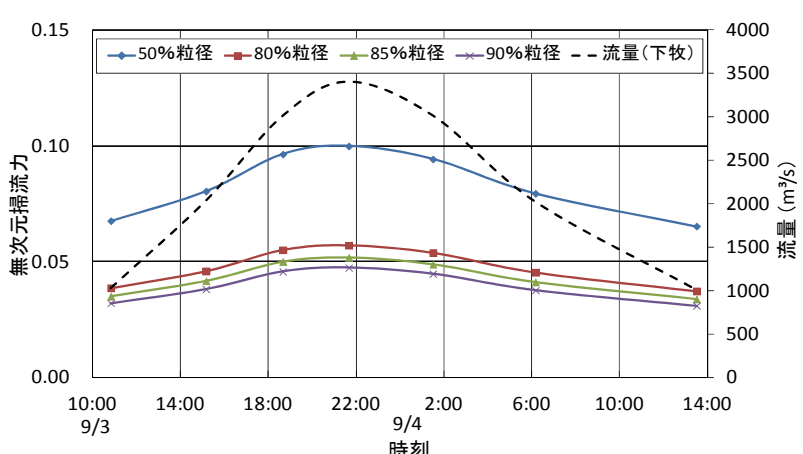

(a) 領域 1 の無次元掃流力

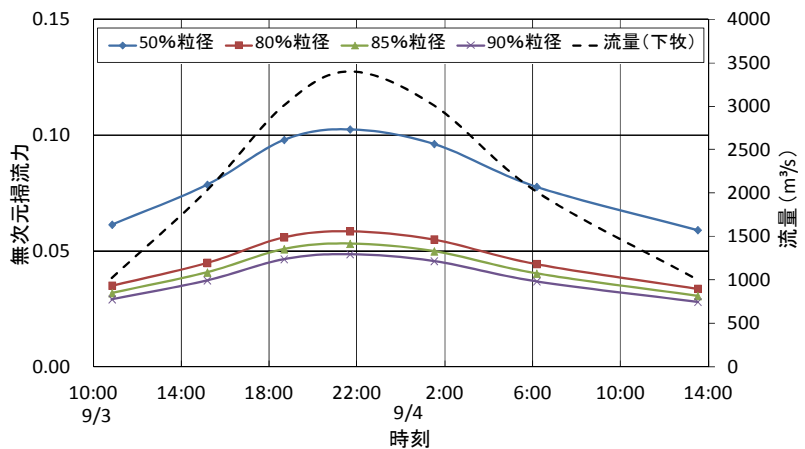

(b) 領域 2 の無次元掃流力

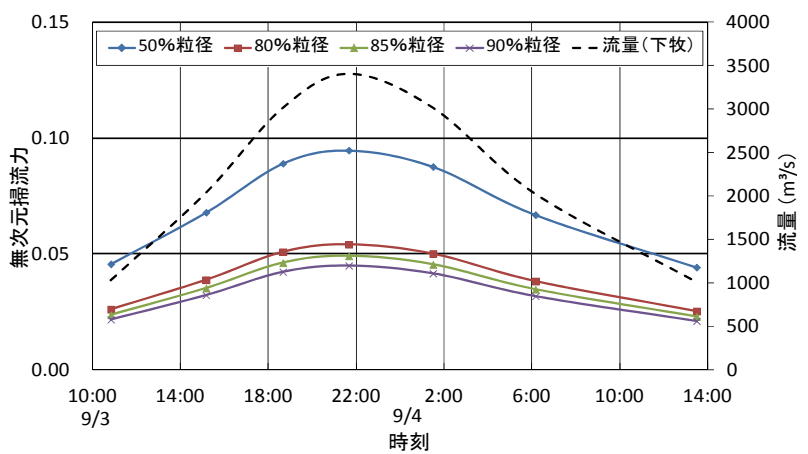

（c） 領域 3 の無次元掃流力

図-10 各領域の粒径別の無次元掃流力の時間変化と流量ハイ ドログラフ(2011 年 9 月洪水)

の領域でほとんどの時間で無次元掃流力が 0.05 を超えて いる. 現地調査の結果から $1000 \mathrm{~m}^{3} / \mathrm{s}$ 程度の出水では，対 象のヤナギは流出してないので，流出条件としては適切 ではない.90\%粒径のときは，逆に全ての領域で無次元 掃流力が 0.05 を超えていないので流出条件としては適切 ではない. 80\%粒径のとき，全ての領域で 8 時間程度以 上無次元掃流力が 0.05 以上となるが領域 3 では流出して いないため現地での流出状況とは一致しない. 85\%粒径 のとき，領域 1, 領域 2 では 6〜 7 時間程度無次元掃流力 が 0.05 を超えているが, 領域 3 では 0.05 を超えていない. つまり，領域 1，領域 2 では植生は流出するが，下流側 の領域 3 では植生は流出しないと考えることができる.

これは現地調査のヤナギの流出結果と比較しても適当で あるといえる。

以上のことから，植生の流出を評価するには $85 \%$ 粒径 で算出した無次元掃流力で評価することが最も望ましい ことがわかる．この流出限界值は，84\%粒径で移動限界 


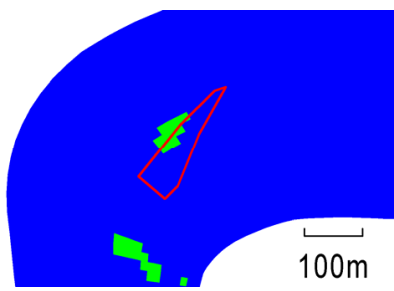

(a) 2011/9/3 10:50 (増水期) 流量 $1028 \mathrm{~m}^{3} / \mathrm{s}$

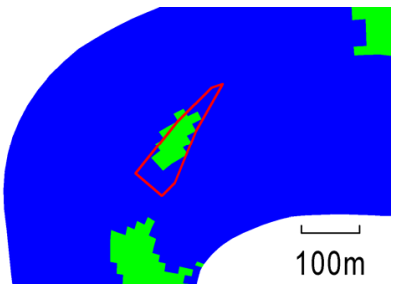

(e) 2011/9/4 1:30 (減水期) 流量 $3012 \mathrm{~m}^{3} / \mathrm{s}$

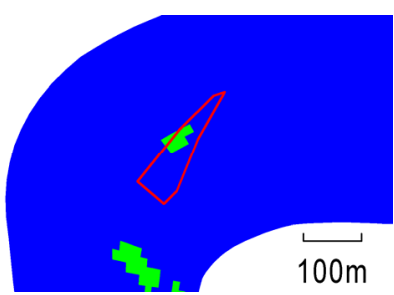

(b) $2011 / 9 / 3 \quad 15: 10$ (増水期) 流量 $2035 \mathrm{~m}^{3} / \mathrm{s}$

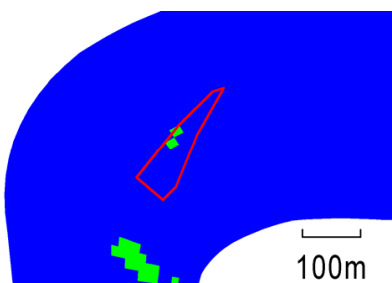

(f) 2011/9/4 6:10 (減水期) 流量 $2020 \mathrm{~m}^{3} / \mathrm{s}$

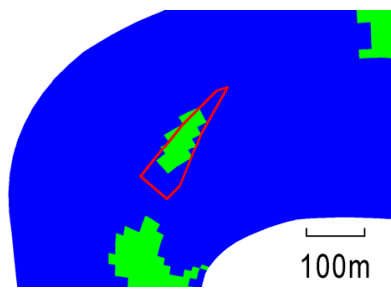

(c) $2011 / 9 / 3$ 18:40（増水期） 流量 $3012 \mathrm{~m}^{3} / \mathrm{s}$

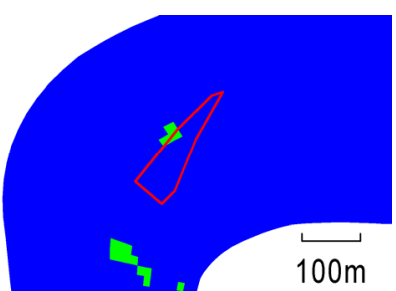

(g) 2011/9/4 13:30 (減水期) 流量 $1007 \mathrm{~m}^{3} / \mathrm{s}$

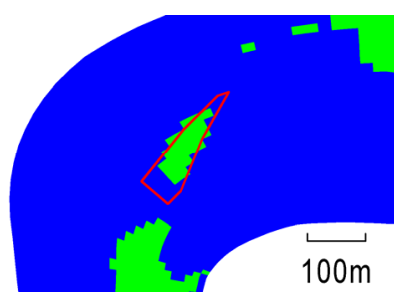

(d) $2011 / 9 / 3$ 21:40 (ピーク) 流量 $3403 \mathrm{~m}^{3} / \mathrm{s}$

無次元掃流力

口: 0.05 未満

$: 0.05$ 以上

図-11 大原箇所付近の 85\%粒径より算出した無次元掃流力の平面分布の時間的変化（赤枠内は大原箇所）

を評価している田中ら ${ }^{5)}$ の值と概ね一致する.

図-11 (a) (g) は洪水期間中の図-1 中の大原箇所（河 口から 16.6〜 $16.8 \mathrm{~km}$ 地点の赤枠内）を含む範囲の $85 \%$ 粒 径で算出した無次元掃流力の平面的な時間的変化を示し ている．青色の部分は，無次元掃流力が 0.05 未満，緑色 の部分が 0.05 以上の箇所である. 無次元掃流力が 0.05 以 上となる箇所は，流量が増加するにつれ範囲は広がって おり, 流量が $3000 \mathrm{~m}^{3} / \mathrm{s}$ 程度に達したあたりから広範囲で 0.05 を超えている. しかし，大原箇所の下流側では無次 元掃流力が最も大きかったと考えられるピーク流量時で も，0.05 を超えておらず，下流側では植生が流出しにく いという現地の状況と一致する.

\section{6. 結論}

本研究では，旭川の大原箇所の植生の生長と洪水時の 植生の流出条件について現地調査と数值解析による検討 を行った. 以下に得られた主要な結論を述べる.

1) 水際部に繁茂するヤナギは, 約 4 年間の調査では年間 約 $0.85 \mathrm{~m}$ の速度で生長し, 夏季の方が冬季よりも速く 生長することが明らかとなった。

2) 河床変動の調査により, 2011 年 9 月洪水により水際部 が大きく侵食された。また，この侵食によりヤナギは 生育基盤ごと流出した.

3) 流量が $1000 \mathrm{~m}^{3} / \mathrm{s}$ 程度の洪水では, 植生は流出しない が, 流量が約 $3400 \mathrm{~m}^{3} / \mathrm{s}$ の洪水では水際部のヤナギの多 くが流出し, 草本類は対象とした全てが流出か埋没し た.このヤナギの流出結果を無次元掃流力で評価する 場合，85\%粒径を用いることが流出限界值として適切 であることが示された。

謝辞 : 本研究を行うにあたり，国土交通省中国地方整備
局岡山河川事務所に多数の貴重なデータを頂いた.また, 本研究の一部は文部科学省科学研究費補助金, 基盤研究 (B)河道内樹林の消長機構に関する水理 ・生態学的解析と 持続的河川管理に向けた戦略研究(代表者 : 道奥康治, 課 題番号 23360212)の援助を受けた。記して謝意を表する.

\section{参考文献}

1）渡辺敏, 前野詩朗, 藤塚佳晃, 宮崎貢, : 旭川における砶河 原再生と樹林化抑制に関する現地試験による検証, 水工学論 文集，第50巻，pp.1201-1206， 2006.

2) 眞田淳二, 浦上将人, 渡辺敏, 前野詩朗, 藤塚佳晃 : 旭川下 流部における礫河原の白律的回復に向けた実証的研究, 河川 技術論文集，第12巻，pp.409-414，2006.

3) 眞田淳二, 浦上将人, 前野詩朗, 渡辺敏 : 2006年7月出水を 経験した旭川下流部磯河原再生箇所のモニタリング結果と 考察，河川技術論文集，第13巻，pp.129-134，2007.

4) 八木澤順治，田中規夫，福岡捷二 : 砂礫州上に繁茂する植生 の洪水時流失限界評価, 河川技術論文集, 第14巻, pp139-144, 2008.

5) 田中規夫，八木澤順治，福岡捷二 : 砂碟上における繁茂場所 の相違が樹木の洪水時流出限界に及ぼす影響, 水工学論文 集, 第53巻, pp.631-636, 2009.

6) 平川隆一, 渡邊訓甫, 小南考輝 : 北川の川坂砂州における地 形変化と草本植生の相互作用について, 土木学会論文集A2, Vol. 68, No. 2, pp.617-624, 2012.

7) 前野詩朗, 渡辺敏, 藤塚佳晃 : 簡易に得られる植生特性值を 考慮した数值解析モデルの精度向上の提案, 土木学会論文集 No.803 / II-73, pp.91-104, 2005.

8) 渡辺敏, 前野詩朗, 渡部秀之, 志々田武幸 : 旭川におけるヤ ナギ林の拡大機構とその抑制管理のあり方に関する検討, 河 川技術論文集，第11巻，pp.77-82，2005.

9）池田裕一，亀田涼，浅枝隆，坂本健太郎 : 渡良瀬川砂州上に おけるハリエンジュの繁茂状況に関する基礎的調査, 河川技 術論文集，第18巻, pp.71-76, 2012. 